\title{
Geographical Aspects of Current Problems
}

$\mathrm{O}^{\mathrm{N}}$ $\mathbf{N}$ January 3, Sir Thomas Holland delivered his presidential address to the Geographical Association, on the occasion of its annual conference at the London School of Economics. Taking as his title "The Geography of Minerals", Sir Thomas gave a penetrating analysis of economic and political effects of the unequal distribution of mineral wealth.

Until the Industrial Rovolution, little interest had been taken in mineral wealth other than the precious metals, and world development was on an agricultural basis. Political boundaries took no notice of mineral fields. The Industrial Revolution placed a new emphasis on coal and iron, and later the development of steel-making and the more recent discoveries of the uses of alloy steəls, together with the expansion of the electrical trades with their great demand for non-ferrous metals such as copper and lead, reoriented the political outlook on minerals. More minerals were actually produced between 1900 and 1925 than during the whole previous history of the world, and although production is still lower in value than that of the field and forest products, it is increasing rapidly, and its effect on political geography is becoming more and more evident.

The possession of, or free access to, a wide variety of minerals is now an essential to the well-being of a great nation, and the unequal distribution of resources, together with the post-War tendency to frustrate the normal or natural movement of raw materials, is at the bottom of much of the present unrest in the world. Both Germany and the Italian Empire are lacking in many of the essential minerals.

It is a striking fact of mineral geography that some seven tenths of the world's iron and steel industry is situated in the countries that border the North Atlantic Ocean. In no other area of the world do coal and iron come together in sufficient quantities ever to give rise to other great steel-producing regions like those of the eastern United States and western Europe. It is this industry which has so largely affected the accessory mineral industries (manganese, chromium, nickel, cobalt, tungsten, etc.). Between them, the United States and the British Empire own about two thirds, and control about three quarters, of the world's mineral industries.

The need for such a wide variety of minerals has meant that the former self-sufficiency of nations in respect of mineral requirements has gone for ever. More than ever before the nations are now interdependent. Here again it is noteworthy, however, that a wide variety of resources occurs in the areas which lie around the North and South Atlantic Oceans. Thus with the British Empire and the United States on friendly terms, and the Atlantic shipping routes under their control, neither Britain nor the United States need have any fears about the supply of any mineral at present considered as vital to industry, whether peaceful or warlike. This rather one-sided position only seems to emphasize the necessity for the interchange of mineral products between the nations, if civilization is not to be destroyed in the revolt of the 'have nots' against the 'haves'.

In a symposium on India, at the same Conference, Sir Thomas Holland contributed a short survey of
India's mineral resources, dealing especially with coal and iron, manganese and chromite. Another con. tribution was from Lord Meston, who described in vivid terms the superimposition of British autocracy, which has converted a congeries of almost medieval peoples into a modern democratic State of 350 million souls, and the difficulties which rapid progress has brought. Dr. L. Dudloy Stamp, in suggesting a division of India into physiographic regions, emphasized that the study of modern geography is still in its infancy in India, and that although the universities are now taking a lead, a vast field of work awaits the geomorphologist in utilizing and correlating the mass of material available in the publications of the Geological Survey and elsewhere. In the meantime, it is important that the main physical features of each of the major regions of India should be understood and regarded as an essential background to human and economic geography. Prof. H.J. Fleure finally gave a brief introduction to the study of the nature and origin of some of the Indian peoples.

Another topical item in the Conference was a lecture by Dr. Hilda Ormsby on the 'Sudeten'-lands. Dr. Ormsby also spoke on the problem of Czechoslovakia to the annual meeting of the Institute of British Geographers, which was in session during the same week. Dr. Ormsby presented a clear picture of the geographical background of the recent crisis. Before the Great War, Bohemia was an outpost of Slavdom, forming the industrial core of the Austrian Empire, and fringed with a population of Germans who had filtered across the mountains from the west during many centuries. The Treaty of Versailles allied the Czechs to the Slovaks and Ruthenians, and cut off the 'Sudeten' Germans of the northern and western fringes of the new State from their Austrian motherland. 'This Bohemian 'salient' of Slavdom became a violent aggravation to the new Reich after the Anschluss, thrusting a spear-head into the heart of Greater Germany. The curious nature of many parts of the 'Sudeten' frontier, which, instead of following sparsely populated, forested country, frequently cut across populous areas, was a natural incitement to the reunion of the German-speaking peoples on either side.

'The 'post-Munich' frontier, however, cannot undermine the essential geographical unity of Bohemia. The similarity of the industrial occupations on both sides of the highland frontier of Bohemia (the Ore Mountains, Giant Mountains and Sudetes) means that the 'Sudeten' lands are economically tributary to the interior of Bohemia rather than to Saxony, and the fact that the Czechs, for some years, had been removing industry from the 'Sudeten' regions into the heart of Bohemia, has rendered these areas poorer and more liable to unemployment. The new Czechoslovakia, although far more homogeneously Slav than ever before, can scarcely be regarded as anything but a puppet State, held together by the power of Germany. The new German motor-road along the Moravian corridor will sever completely the western and easterm parts of the country, and the main lines of rail communication between east and west have already been cut by the new frontiers in several places.
S. H. Beaver. 